\title{
Omurilik kılavuz aparatı
}

\author{
Spinal guidance device
}

\author{
Alpaslan Şenköylü \\ Gazi Üniversitesi Tıp Fakültesi, Ortopedi ve Travmatoloji Ana Bilim Dalı, Ankara
}

Buluş, kompleks omurga sorunu (deformite, tümör, travma, enfeksiyon, dejeneratif nedenlere bağlı gelişebilen) nedeniyle omurga ameliyatı planlanan hastaların boyun (cervical), gögüs (thoracic) veya bel (lumbar) omurlarına hatasız bir şekilde uygulanacak, bilgisayarlı planlama ve 3D basılmış kılavuz implantlar ile ilgilidir.

Anahtar sözcülkler: omurga; pedikül vidası; skolyoz; kifoz; omurga defomitesi; 3D yazıcı

\section{T. C. Türk Patent Enstitüsü'ne Faydalı Model Belgesi için Başvuru Bilgileri[ ${ }^{1]}$}

Başvuru bilgileri Tablo 1'de gösterilmiştir. ${ }^{[1]}$

Tablo 1. Başvuru bilgileri ${ }^{[1]}$

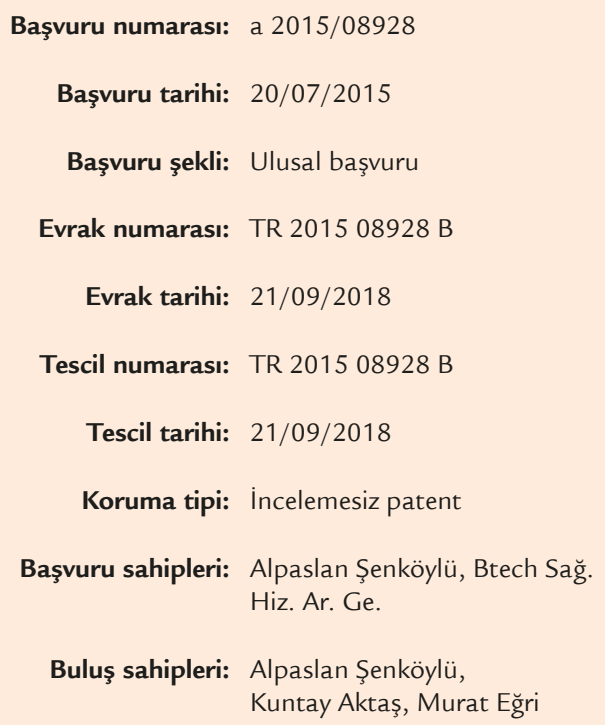

The current invention relates to preoperative computer modelling and 3D printed guides which will be applied to cervical, thoracic or lumbar vertebrae of patients who have a complex spinal disorder (deformity, tumor, trauma, infection, degenerative).

Key words: spine; pedicle screw; scoliosis; kyphosis; spine deformity; 3D printer

\section{Teknik Alan ${ }^{[1]}$}

"Buluş, kompleks omurga sorunu (deformite, tümör, travma, enfeksiyon, dejeneratif nedenlere bağlı gelişebilen) nedeniyle omurga ameliyatı planlanan hastaların boyun (cervical), gögüs (thoracic), bel (lumbar) omurlarına veya kuyruk sokumu kemiğine (sacrum) hatasız bir şekilde uygulanacak, bilgisayarlı planlama ve 3D basılmış kılavuz implantlar ile ilgilidir."

\section{Önceki Teknik/Teknikler[1]}

"Omurganın kompleks sorunları oldukça geniş spektrumdaki hastalıkları içerir. Bu hastalıkların her biri kendi içinde farklı yöntemlerle tedavi edilmeye çalışılır. Aslında tüm bu patolojilerin bir kısmı konservatif veya cerrahi olmayan yöntemlerle çözümlenebilmektedir. Ancak omurga stabilitesinin bozulduğu durumlar, nörolojik bulguların varlığı, progresif (ilerleyici) deformite, tüm konservatif tedavilere karşın geçmeyen ağrı veya konservatif tedaviyle kür şansı olmayan durumlarda cerrahi tedavi ön plana çıkmaktadır.

- Illetişim adresi: Prof. Dr. Alpaslan Şenköylü, Gazi Üniversitesi Tıp Fakültesi Ortopedi ve Travmatoloji Ana Bilim Dalı, 06510 Beşevler, Ankara Tel: 0555 - 2697998 e-posta: drsenkoylu@gmail.com ORCID iD: 0000-0001-6870-5515

- Geliș tarihi: 6 Kasım $2020 \quad$ Kabul tarihi: 16 Kasım 2020 
Özellikle skolyoz, kifoz veya kifoskolyoz gibi omurga deformitelerinde zaten kompleks olan anatomik yapılar orijinal biçimlerinden daha farklı bir hal alır. Özellikle axial (aksiyel) düzlemdeki rotasyon, pedikül çapının küçülmesi ve kemik yapıların biçim değiştirmesiyle, zaten zor olan omurgaya implant yerleştirme işlemi iyice güçleşir.

Tekniğin bilinen durumunda uygulanacak tedavi yöntemlerinden biri olan açık cerrahi seçenekte çeşitli implantlar geliştirilmiştir. Bu implantlar genel olarak, bir oksipital plak, omurga kemiklerinin farklı bölümlerine (pedikül, lateral kitle, faset eklem) yerleştirilen vidalar, vidaları birbirlerine bağlayan rodlar, rodları vidalara sabitleyen kafa ve vidalardan meydana gelmektedir.

Birçok farklı yöntem olduğu hâlde en yaygın omurga sabitleme, pedikül vidalarla sabitlemedir. Tekniğin bilinen durumunda CN103340682, WO2013177314, US2007233094 sayılı patent başvurularında söz konusu pedikül vidaların çeşitlerinden bahsedilmiştir. Sözkonusu pedikül vidaları pedikülden geçerek vertebraya girdiği için aynı anda 2, hatta 3 kolonlu bir stabilizasyon sağlamaktadır. Bu yüzden pediküler fiksasyon (sabitleme) enstrümentasyonu çok yaygın uygulama alanı bulmuştur.

Ancak pedikül vidalarıyla omurga sabitlemesinde karşılaşılan en önemli sıkıntı çevresinden geçen damar, sinir gibi hayati yapılardır. Bir de buna deformitelerdeki kemik yapı bozuklukları eklenince implantların konumunu belirlemek zorlaşmaktadır. Bu vakalarda vertebranın şekilsel bozukluğundan dolayı pedikül vidaların sabitlenmesi imkânsız hale gelmektedir.

Omurganın değişik kısımlarına ait vertebralar arasında şekil ve büyüklük bakımından farklılık göstermektedir. Bu farklılıklardan kaynaklı olarak her vertebra için aynı cerrahi operasyonun uygulanması mümkün olmamaktadır. Boyun (cervical) vertebraları yapısal olarak diğer vertebralardan daha farklı olup, cerrahi operasyonda daha fazla dikkat ve beceri istemektedir. Operasyonu uygulayacak olan cerrahın, el becerisine ve dikkatine bağlı olan bu tedavilerde yapılacak en ufak hata felç veya ölüm gibi geri dönüşü olmayan sonuçlara sebep olabilmektedir.

Bu şekil farklılıklarına göre sınıflanan omurlar 5 grupta ele alınmaktadır.

Servikal vertebralar: Kafatası bitim noktasından başlayıр, enseköküne kadar uzanan boyun bölgesindeki 7 omur servikal vertebralar olarak adlandırılmaktadır. Kollar, ellerin motor (hareket) ve duyu (his) faaliyetleri omuriliğin bu seviyedeki bölgeleri tarafindan kontrol edilmektedir. Ĕger omurgada meydana gelen bir hasar bu bölgede omuriliğe zarar verirse, vücudun kollar ve aşağısındaki bölgeleri felç olacaktır. Kuadripleji (quadriplegia) olarak adlandırılan bu felç türünde solunum hareketini kontrol eden kaslar da etkileneceği için ölüm riski de söz konusu olabilir.
Torakal (thoracic) Vertebralar: Ense kökünden başlayıp, kaburgaların omurgayla birleştiği son noktaya kadar olan 12 vertebraya verilen addır. Bu omurlar; gövde bölgesine ait motor ve duyuyu kontrol etmektedir. Ĕger hasar bu bölgede gerçekleşir ve bir felç yaşanırsa, gövde ve aşağısında kalan bölgede, yani ayaklar, genital ve seksüel yetenekler üzerindeki kontrol ortadan kalkacak, (bacaklar ve ayaklar işlev kaybedeceği için) paraplejik felç yaşanacaktır.

Lomber Vertebralar: Torakal vertebralardan sonra bel bölgesini tutan 5 tane vertebraya lomber vertebralar adı verilmektedir. Lomber vertebralarda oluşan bir hasar omuriliğe bası yaparsa paraplejik felç yaşanacak; bacaklar ve aşağı bölgede kalan fonksiyonlar, yani genital ve seksüel yetenekler üzerindeki kontrol ortadan kalkacaktır.

Sakral Vertebralar: Kuyruk sokumu bölgesindeki 5 vertebraya verilen addır. Bu vertebralar, (diz altında kalan) ayakları ve seksüel - genital işlevleri kontrol eder. Bu bölgede yaşanacak bir hasar sonucunda ayaklar ve genital - seksüel fonksiyonlarda duyu ve motor faaliyetler kaybedilecektir.

Bu şekilde sınıflandığında omurların içte kalan tambur şeklindeki oval kısımlarına cisim (corpus), sağında ve solunda kalan çıkıntılarına transvers çıkıntı, arka kısmında kalan boynuz şeklindeki uzantıya da spinöz çıkıntı adı verilmektedir. Vertebralar, birbirlerine aralarındaki intervertebral disk adı verilen yastıklarla bağlanmaktadır.

Vertebraların ve kraniyoservikal bileşkenin gelişimsel anomalileri her yaşta görülebilir. Uygun yaklaşım için bu türden anomalilerin bilinmesi ve saptanması oldukça önemlidir.

Servikal bölge, içerdiği yaşamsal oluşumlarla baş ile gövdeyi birleştiren önemli bir bölgedir. Bu bölgenin değerlendirilmesinde direkt radyografiler ilk teşhisin konulmasında kullanılmaktayken, değişik planlarda inceleme, gereksinimi durumunda bilgisayarlı tomografi (BT), manyetik rezonans görüntüleme (MRG) gibi kesitsel görüntüleme yöntemlerine de başvurulmaktadır. Bu görüntüleme sistemlerinden alınan veriler ile vertebraların durumları net bir şekilde görülüp, uygulanacak cerrahi tedavi yöntemi seçilebilmektedir.

Servikal ve diğer bölgelerde bulunan vertebraların görüntüleme sistemleri yardımıyla durumlarının belirlenmesi en sağglıkı yöntem olmasının yanında tedavi aşamasında yapılacak olan cerrahi operasyon yine cerrahın becerisine ve dikkatine kalmaktadır.

$\mathrm{Bu}$ nedenle ve yukarıda anlatılan dezavantajlar göz önünde tutularak cerrahi uygulama yapılacak olan hastanın $3 D$ anatomik yapılarının $M R$ veya $B T$ görüntülerinden kesitler alınarak modellenmesi ve bilgisayar ortamında damar, sinir ve kemik yapılar topografik olarak hesaplanarak kemik analizleri yapılarak vidanın uygulanacağı kemik 
yapının (pedikül, lateral kitle, faset eklem) hem kalite hem de boyut olarak en optimal bölgesinden, optimal doğrultuda gönderilecek vida yolu tasarlanmıştır."

\section{Buluşun Kısa Tarifi ${ }^{[1]}$}

"Buluşun amacı, cerrahi uygulama yapılacak olan hastanın 3D anatomik yapılarının $M R$ veya $B T$ görüntülerinden kesitler alınarak modellenmesi ve bilgisayar ortamında damar, sinir ve kemik yapılar topografik olarak hesaplanarak, kemik analizleri yapılarak vidanın uygulanacağı kemik yapının (pedikül, lateral kitle, faset eklem) hem kalite hem de boyut olarak en optimal bölgesinden, optimal doğrultuda gönderilecek vida yolunun planlanabilmesidir.

Buluşun bir diğer amacı, omurga cerrahisi kılavuz sistemi ile vida uygulaması yapılacak olan hastanın her bir omuru için ayrı ayrı özel olarak tasarlanmasıdır.

Buluşun bir diğer amacı da, her bir vertebra için ayrı ayrı tasarlanan kılavuz sisteminin mükemmel bir biçimde vida yerleştirilmesini sağlamasının yanında düşük profilde olmasının gerekmesidir."

\section{Buluşun Detaylı Açıklanması ${ }^{[1]}$}

"Buluş ile kompleks omurga sorunu (deformite, tümör, travma, enfeksiyon, dejeneratif nedenlere bağlı gelişebilen) nedeniyle omurga ameliyatı planlanan hastaların boyun (cervical), göğüs (thoracic) ve bel (lumbar) vertebralarına (1) veya kuyruk sokumu (sacrum) kemiğine implant (vida) uygulamasının bilgisayarlı planlama ve 3D basılmış kılavuzlar ile hatasız yapılması için kullanılan plastik ve/ veya metal malzemeden mamul bir kılavuz aparatı (2) ile ilgilidir.

Şekil 1a, 1b, 1c, 1d ve 1e'de sırasıyla boyun, göğüs, bel vertebraları ve kuyruk sokumu (sakrum) kemiği (1) genel görünümleri verilmiştir. Yukarıdan aşağıya inildikçe hem derinliği hem de genişliği artan vertebraların (1) iki önemli kemik bölümü olup bunlar korpus ve posterior elemanlardır. Üst servikal ve alt kraniyum arasındaki komplike kemik yapılar dışında, vertebral kolonun diğer bölümlerinde anatomileri birbirine benzer. Bu benzerlikler göz önünde tutularak buluş konusu kılavuz aparatı (2) geliştirilmiştir.

Kılavuz aparatı (2), vertebraların (1) implant (vida) uygulamasında vidanın gönderileceği eklem çıkıntısına (1.3) oturması için vertebraların (1) benzer olan yapılarından iki yan çıkıntısı (1.1) bir dikensi (1.2) çıkıntısı olmak üzere toplam üç referans noktası dikkate alınarak oluşturulmuştur.

Şekil 2'de gösterilen kılavuz aparatı (2), eklem çıkıntısından (1.3) matkapla vida yolunun (5.1) açılabilmesi ve bu vida yolu (5.1) içerisinden vidanın mükemmel bir şekilde gönderilebilmesini sağlamaktadır. Böylece, omuriliğe zarar verme riski minimum düzeye indirilmiştir.
Kılavuz aparatı (2) cerrahi operasyonu yapılacak olan her bir vertebra (1) için ayrı ayrı 3D anatomik yapıları $M R$ veya $B T$ görüntülerinden 0,1-0,9 mm'lik ince kesitler alınarak modellenir ve bilgisayar ortamında damar, sinir ve kemik yapılar topografik olarak hesaplanır. Hesaplanan bu modeller üzerinden kemik analizleri yapılarak vidanın uygulanacağı kemik yapının (pedikül, lateral kitle, faset eklem, lamina) hem kalite hem de boyut olarak en optimal bölgesinden, optimal doğrultuda gönderilecek vida yolunun (5.1) üzerinden bulunduğu eklem çıkıntı yatağı (5) ve bu vida yoluna (5.1) kılavuzluk edecek yan çıkıntı yatakları (3) ve dikensi çıkıntı yataklarının (4) alt yüzeyleri modellenir.

Vidanın en düzgün şekilde kemik içerisine yerleştirilebilmesi için bu vida yoluna (5.1) kılavuzluk edecek ve operasyon sırasında vida yolunun (5.1) sabit bir şekilde vertebra (1) üzerinde kalması için yan çıkıntılarından (1.1) ve dikensi çıkıntısından (1.2) destek alınarak, yan çıkıntı yatakları (3.2) ve dikensi çıkıntı yatağı alt yüzeyi (4.1) oluşturulur.

Yan çıkıntı yatağı alt yüzeyi (3.2) ile dikensi çıkıntı yatağı alt yüzeyi (4.1) üzerinde konumlanacă̆ı kemikler ile anahtar kilit ilişkisine sahiptir. Yan çıkıntı yatağı alt yüzeyi (3.2) ile dikensi çıkıntı yatağı alt yüzeyi (4.1) girdili çıktılı düz olmayan bir yüzeye sahiptir. Yan çıkıntı yatağı (3) ve dikensi çıkıntı yatağı (4) silindirik forma sahip olup, merkezlerinde metal çıkıntı (3.1) bulunmaktadır.

Kılavuz aparatı (2); dikensi çıkıntısıyla (1.2) uyumlu yapıya sahip olan bir dikensi çıkıntı yatağına (4), her iki yan çıkıntıları (1.1) ile uyumlu yapıya sahip yan çıkıntı yataklarına (3) ve vidanın geçirileceği eklem yüzeyi ile uyumlu eklem yataklarına (5) sahiptir.

Kılavuz aparatının (2) vertebraya (1) tam olarak anahtar-kilit ilişkisi ile yerleştirileceği ve vidanın geçirileceği bölge ile kılavuz aparatının (2) kemiğe oturtulduğu yan çıkıntı yatakları (3) ve dikensi çıkıntı yatağının (4) farklı yerler olmasıyla hem yapının mukavemetinin artırılmasını hem de düşük profile sahip olması sağlanmıştır. Böylece operasyonu uygulayacak olan cerrahın en düzgün ve risksiz bir şekilde kemiğe vidayı sabitleyebilecektir. Düşük profilli kılavuz aparatı (2) sayesinde kılavuz aparatı (2) kemiğe veya vertebraya daha düzgün ve destekli bir şekilde oturtulabilmektedir.

Kılavuz aparatında (2), operasyonun uygulanacă̆ı kemik yapısına göre; yan çıkıntı yataklarının (3) her birine bağlantı yoluyla (2.1) bağlı olan veya bitişik olan eklem yatakları (5) bulunmaktadır. Söz konusu eklem çıkıntı yatakları (5); cerrahi operasyon yapılacak hastanın boyun, göğüs, bel veya kuyruk sokumu vertebrasına göre yan çıkıntı yataklarına (3) bitişik olabilir veya yan çıkıntı yataklarına (3) bağlantı yolu (2.1) ile bağlanabilir veya yan çıkıntı yatakları (3) ile üst üste binmiş olabilir. Bu şekilde genel 
hatları ile oluşturulan kılavuz aparatının (2), mukavemetin artırılması ve eklem çıkıntı yatakları (5) ile yan çıkıntı yatakları (3) ve dikensi çıkıntı yatağı (4) arasındaki koordinasyonu sağlamak için bağlantı yolları (2.1) artırılabilir. Bağlantı yolu (2.1), kılavuz aparatının bir eklem çıkıntı yatağı (5) ile bir yan çıkıntı yatağı (3) arasında olacak şekilde konumlanmaktadır.

Buluş konusu kılavuz aparatı (2), omurganın şekil 16'de gösterilen servikal (10) kısmında kullanılmak istenildiğinde, en kraniyeldeki servikal vertebrası (1) için şekil 1a'da gösterilen yan çıkıntılara (1.1) ve dikensi çıkıntıya (1.2) oturacak şekilde tasarlanmıştır. Bu vertebrada (1) genel yapısı itibariyle, yan çıkıntı (1.1) ve eklem çıkıntısı (1.3) aynı yer olduğu için; kılavuz aparatında (2) destek elemanı olan yan çıkıntı yatağı (3) ile eklem çıkıntı yatağı (5) aynı yer olarak tasarlanır ve üst üste binmiş yapıdadır. Bu hali ile elde edilen kılavuz aparatı en kraniyeldeki vertebra (1) için iki bağlantı yoluna (2.1), bir dikensi çıkıntı yatağına (4) ve üst üste binmiş eklem çıkıntı yatağı (5) ile yan çıkıntı yatağına (3) sahiptir.

Buluş konusu kılavuz aparatı (2) kuyruk sokumu (sacral) kemiğin üzerinde kullanılmak istendiğinde ise, yapısal şeklinden kaynaklı olarak; şekil 9 ve şekil 10'da gösterildiği üzere bir eklem çıkıntı yatağı (5) ve bir yan çıkıntı yată̆ı (3) arasında fazladan bir bağlantı yolu (2.1) konumlanmaktadır.

Buluş konusu kılavuz aparatının (2) örnek bir kullanımı şekil 11'de gösterilmiştir. Şekil 11'de vertebra (1) üzerinde yer alan üç referans noktası olan iki yan çıkıntı (1.1) ve bir dikensi çıkıntı (1.2) baz alınarak kılavuz aparatı (2) oturtulmuştur. Dikensi çıkıntı (1.2) üzerine dikensi çıkıntı yatağı (4) gelirken, yan çıkıntılar (1.1) üzerine yan çıkıntı yatakları (3) oturtulur. Böylece vida yolunun açılacağı ve buradan implantın yerleştirileceği yer olan eklem çıkıntısı (1.3) üzerine eklem çıkıntı yatağı (5) konumlanır. Yan çıkıntı yatağı (3.2) ve dikensi çıkıntı yatağı (4.1) merkezinde yer alan metal çıkıntıların (3.1) üzerine bastırıldığında ise sivri uçları yan çıkıntılara (1.1) ve dikensi çıkıntıya (1.2) geçirilerek kılavuz aparatının (2) vertebra (1) üzerine sabitlemesi yapılarak operasyona hazır duruma getirilir.

Yan çıkıntılar (1.1) ve dikensi çıkıntı (1.2) için oluşturulan çıkıntı yatağı (3) ile dikensi çıkıntı yatağı (4), vertebra (1) çıkıntılarının oluşturduğu yüzeye; yan çıkıntı yatağı alt yüzeyinden (3.3) ve dikensi çıkıntı yatağı alt yüzeyinden (4.1) oturtulur. Yan çıkıntı yatağı alt yüzeyinde (3.2) ve dikensi çıkıntı yatağı alt yüzeyinde (4.1) en az bir adet metal çıkıntı (3.1) yer almaktadır. Söz konusu metal çıkıntı (pin, sivri uç), yan çıkıntı yatağı (3) ve dikensi çıkıntı yatağının (4) merkezinde konumlanmış olup, vertebra çıkıntıları ile temas edecek yüzey üzerinde ve kılavuz aparatının (2) vertebraya sabitlenmesini sağlamaktadır. Bu sabitleme ile, vida yolunun (5.1) üzerinde yer aldığı eklem çıkıntı yatağından (5) içerisinden geçirilip vertebraya sabitlenecek olan vidanın operasyon sırasında kayması ve istenmeyen hatalara yol açması önlenmiş olmaktadır.

Tekniğin bilinen durumunda en çok karşılaşılan sorunlardan biri olan kullanılan kılavuz aparatlarının yüksek profile sahip olmasının önüne geçilmiştir. Kılavuz aparatının (2) sahip olduğu, yan çıkıntı yatakları (3) ve dikensi çıkıntı yataklarının (4) ayrı yapılar olması sayesinde profilin düşürülmesi sağlanmış ve tekniğin bilinen durumunda kullanılan kılavuz aparatlarına (2) göre daha düşük profilli bir yapı ortaya çıkarılmıştır. Söz konusu yan çıkıntı yatakları (3) ve dikensi çıkıntı yatakları (4) sayesinde vidanın geçirilmesi işlemi sırasında referans alınacak noktaların belirlenmesi kolaylaşmıştır.

Buluş konusu kılavuz aparatı(2); dikensi çıkıntı (1.2) üzerine konumlanacak olan ve dikensi çıkıntıya (1.2) temas edecek yüzeyi ile anahtar kilit ilişkisine sahip olan dikensi çıkıntı yatağı (4); diğer iki yan çıkıntıları (1.1) üzerinde konumlanacak olan ve yan çıkıntısına (1.1) temas edecek yüzeyi ile anahtar kilit ilişkisine sahip olan yan çıkıntı yată̆ı (3) ile bağlantı yolları (2.1) ile birbirlerine montajlanmışlardır. Yan çıkıntı yatağı (3), dikensi çıkıntı yatağı (4) ve eklem çıkıntı yatakları(5) montajlama işlemi sonrasında, farklı geometriye sahip olabilmektedirler.

Bağlantı yolu (2.1), yan çıkıntı yatakları (3) ve eklem çıkıntı yată̆ı (5) ile yekpare olup, dikensi çıkıntı yată̆ına (4) şekil 8'de gösterilen bağlantı noktasındaki modüler kilit (2.2) ile kılavuz aparatına (2) montajlanır. Söz konusu modüler kilit (2.2), sayesinde, kılavuz aparatının (2) modüler olması sağlanmıştır. Böylece, operasyonu yapacak olan cerrah, matkapla vida yolunu (5.1) açtıktan sonra kılavuz sistemini (2) kaldırıp kemiğe yerleştirilen $K$-teli (Kirschner teli) üzerinden vidayı serbest elle kemiğe yerleştirebilir. Pediküllerin aksiyel düzlemde konverjan yerleşimli olmaları nedeniyle monoblok bir kılavuz aparatında (2) K-tellerini yerlerinde bırakarak sökülmesi mümkün değildir. Bunun için her iki pedikül için tasarlanmış olan kılavuz aparatı (2) dikensi çıkıntı yatağı (4) üzerine yerleşen bağlantı noktasındaki modüler kilit (2.2) ile ayrilabilmektedir.

Kılavuz aparatındaki (2) dikensi çıkıntı yatağı (4) ve yan çıkıntı yatakları (3), bağlantı yolunun (2.1) referans alınması ile bağlantı yolunun (2.1) altında kalacak şekilde veya bağlantı yolunun (2.1) üzerinde kalacak şekilde, tek yönlü uzayan silindirik yapıya sahiptir.

Eklem çıkıntı yatağı (5) ise, bağlantı yolunun (2.1) referans alınması ile bağlantı yolunun (2.1) hem altında hem de üstünde çift yönlü olarak uzayan silindirik yapıya sahiptir.

Buluş konusu kılavuz aparatı (2) kullanılarak yapılacak olan operasyonlarda, eklem çıkıntı yatağı (5) içerisinde yer alan vida yolundan (5.1) içeri matkapla yol açar. Açılan yola K-teli yerleştirilir. Bu işlem sırasında, vida yolundan 
(5.1) geçen matkap ucunun, dönme etkisi ile vida yoluna (5.1) zarar vermemesi ve planlama açılarının sapmaması için vida yolunun (5.1) iç yüzeyine paslanmaz çelik boru formu geçirilir.

Şekil 7'de eklem çıkıntı yatağı (5) ve ona montajlanmış bağlantı yolunun (2.1) kesit görüntüsü verilmiştir. Buluş konusu kılavuz aparatının (2) düşük profil yapısına haiz olması sebebiyle, mukavemetinin sağlamlaştırılması için, bağlantı yollarının (2.1) içerisinden paslanmaz teller (2.1.1) geçirilmiştir. Söz konusu paslanmaz teller (2.1.1) metal yapıya sahip olup, bağlantı yolunun (2.1) kalınlığı ile orantılı olacak şekilde 0,5-1,5 mm çapına sahiptir.

Geliştirilen düşük profilli kılavuz aparatı (2) ile posterior ligamentöz kompleks tamamen sıyırılmadan kılavuz aparatı (2) kemik üzerine oturtulabilmesi sağlanmıştır.”

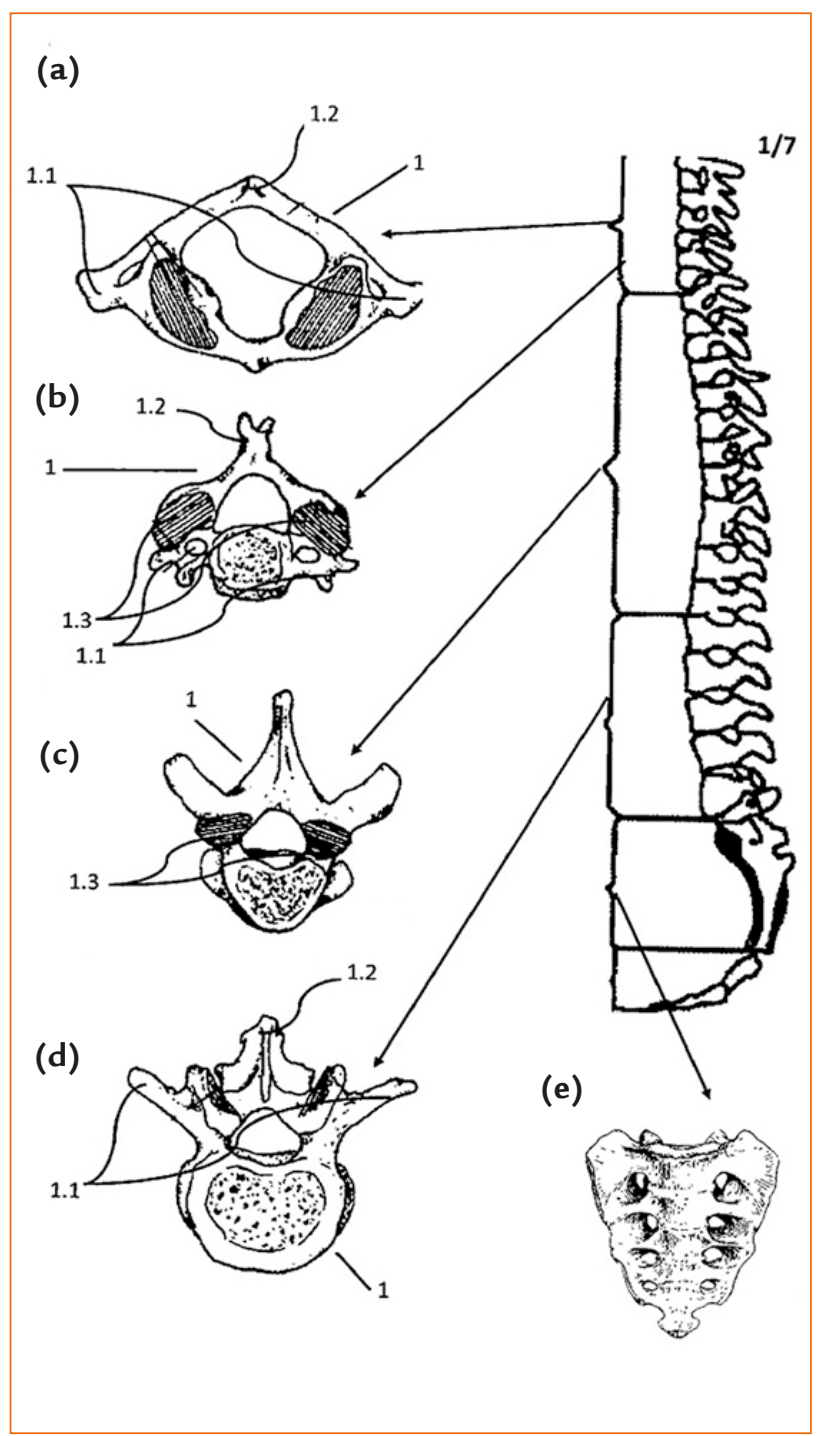

Şekil 1. a-e. Omurga bölümleri. En kraniyeldeki vertebra (a). Boyun vertebrası (b). Göğüs vertebrası (c). Bel vertebrası (d). Sakrum kemiği (e).

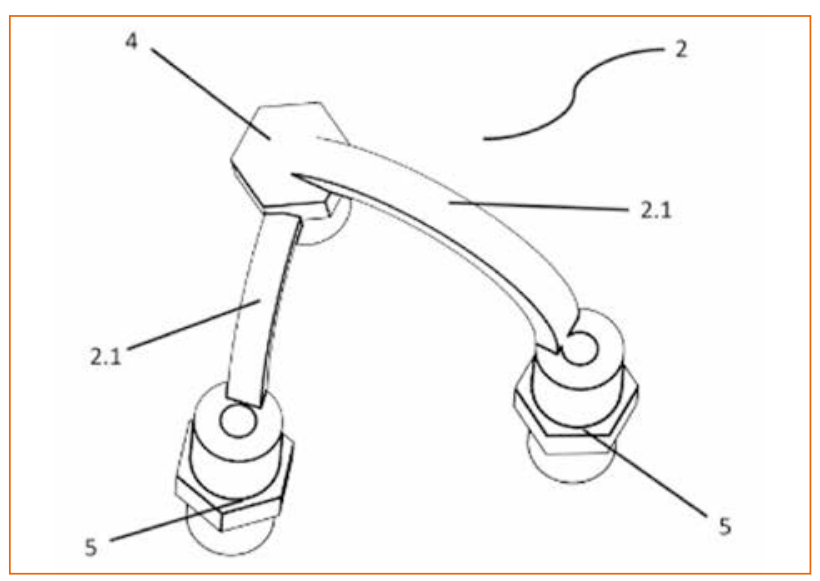

Şekil 2. En kraniyeldeki vertebra için kılavuz aparatı; üstten görünüşü.

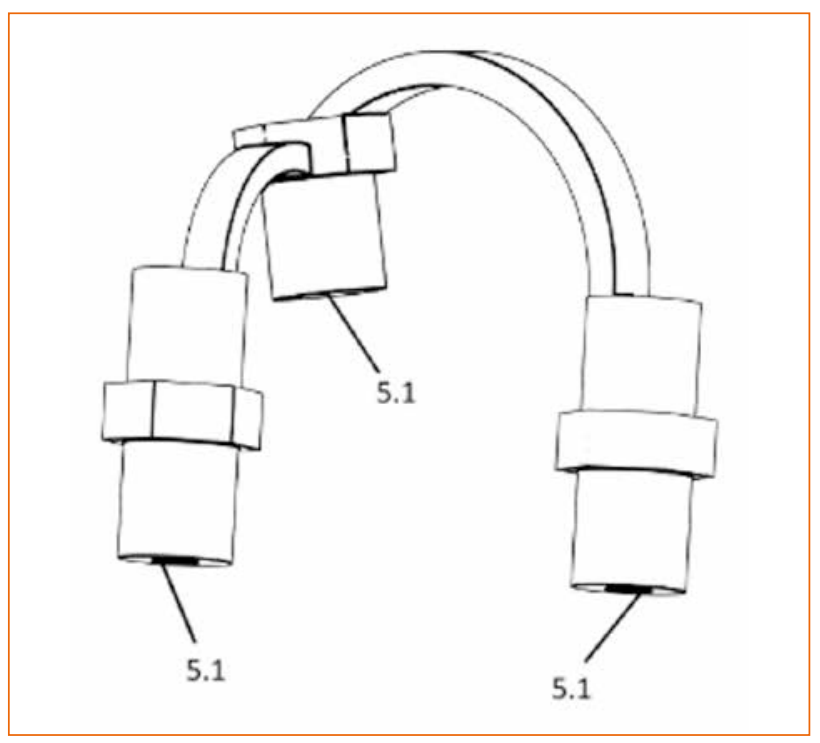

Şekil 3. En kraniyeldeki vertebra için kılavuz aparatı; perspektif görünüşü.

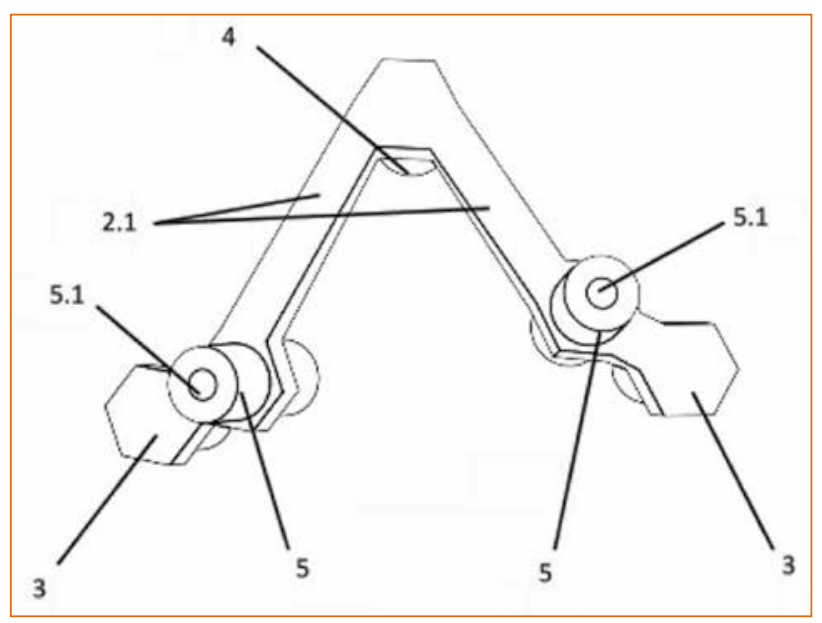

Şekil 4. Boyun, göğüs, bel vertebrası için kılavuz aparatı; üstten görünüşü. 


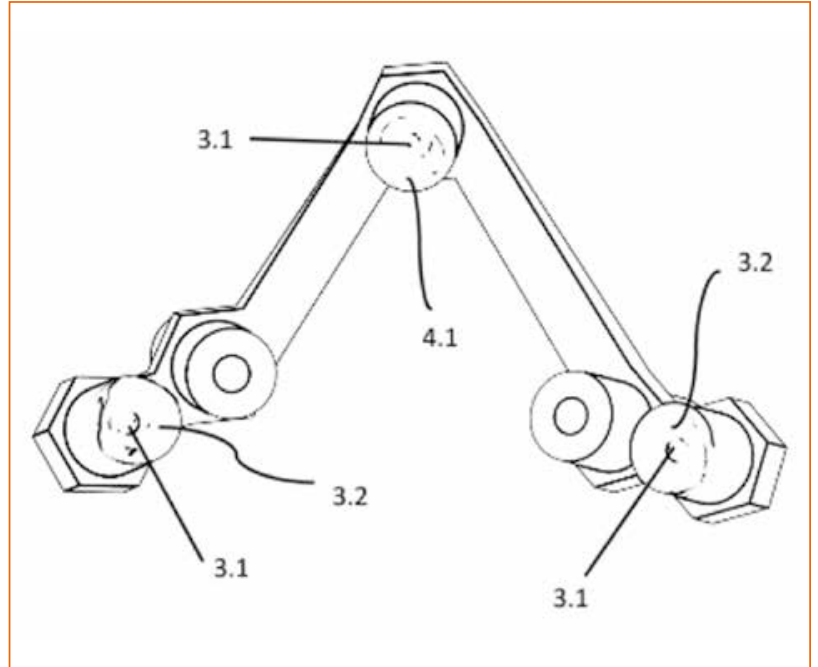

Şekil 5. Boyun, göğüs ve bel vertebrası için kılavuz aparatı; alttan görünüşü.

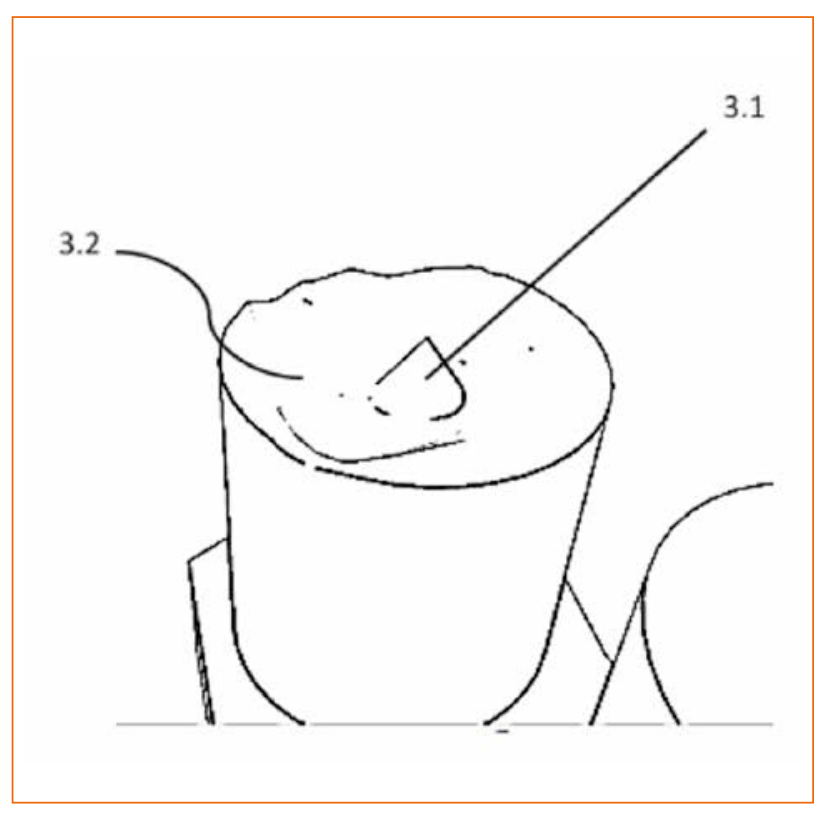

Şekil 6. Yan çıkıntı yatağı ve metal çıkıntı.

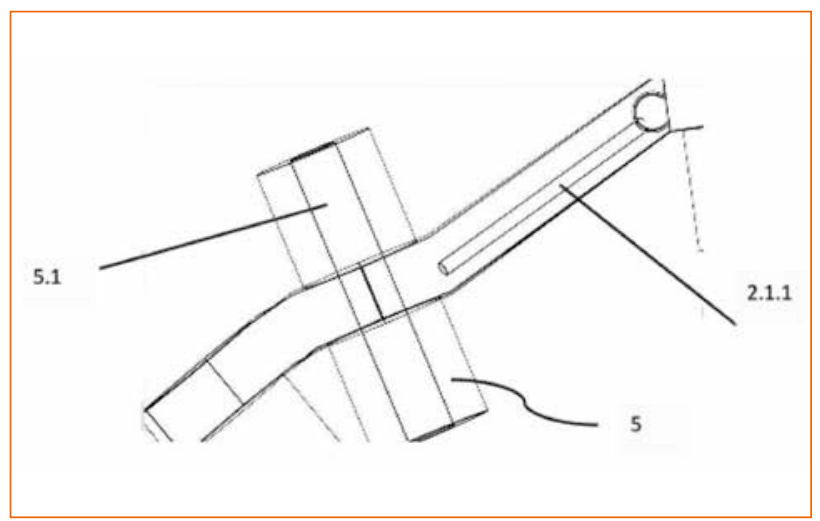

Şekil 7. Bağlantı yolu içerisindeki paslanmaz tel.

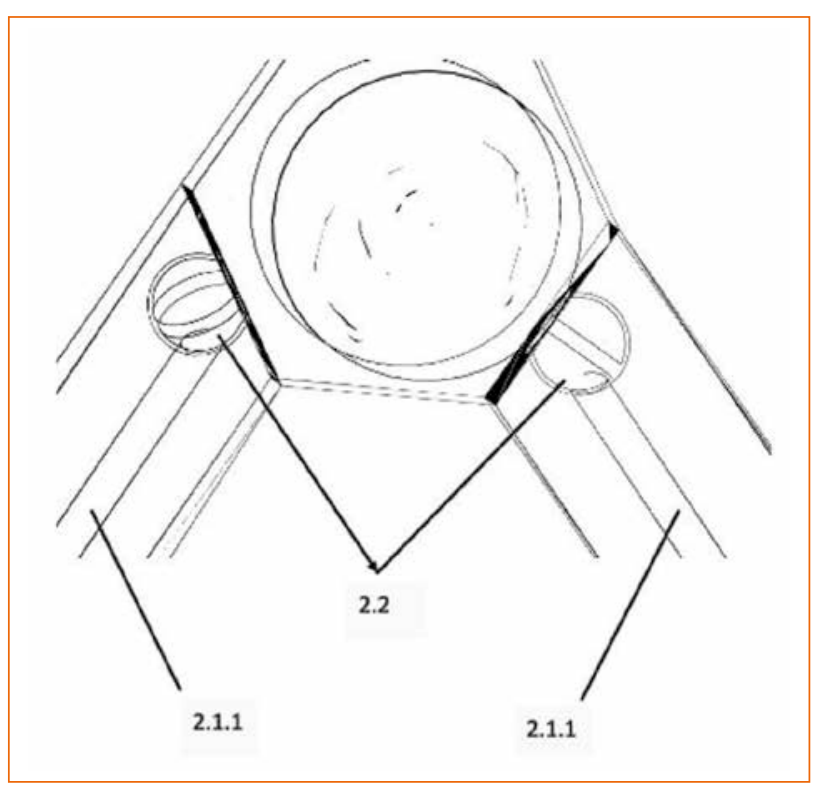

Şekil 8. Modüler kilit ve paslanmaz tel.

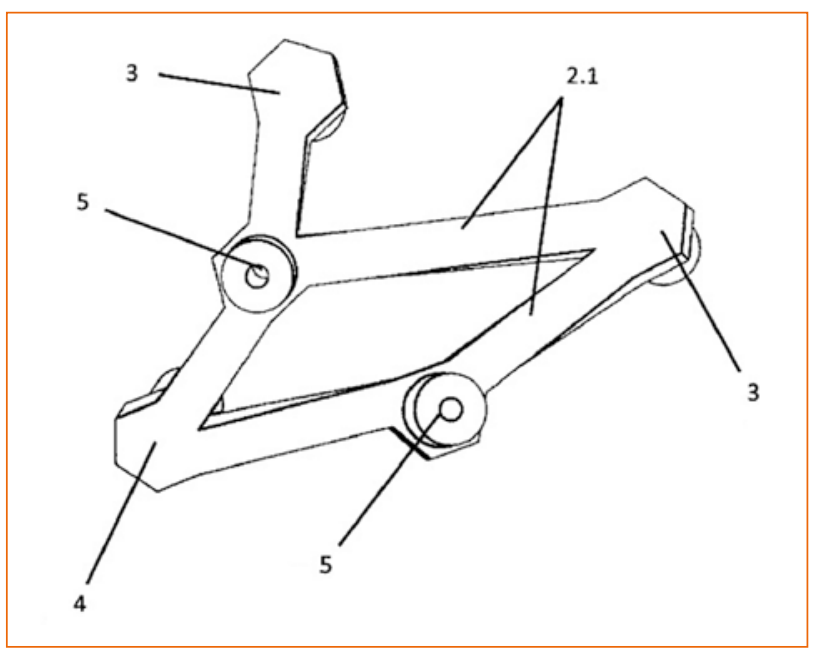

Şekil 9. Kuyruk sokumu vertebrası için kılavuz aparatı; üstten görünüşü.

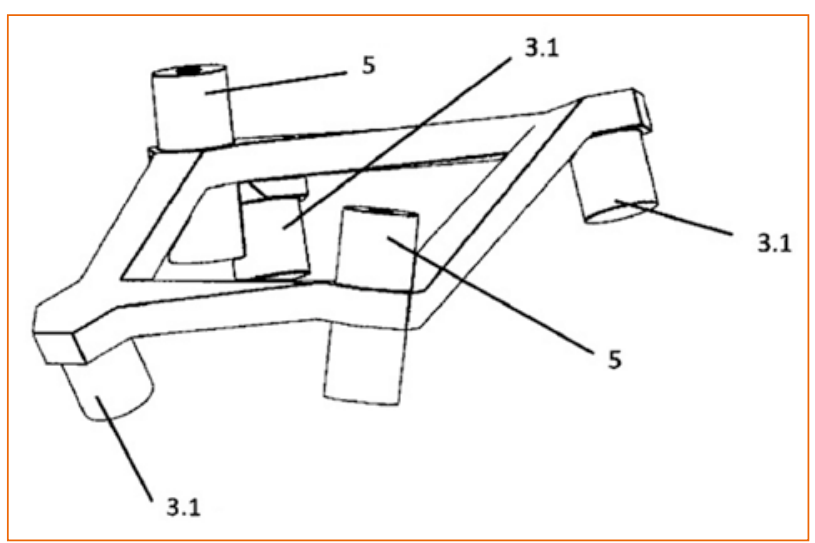

Şekil 10. Kuyruk sokumu vertebrası için kılavuz aparatı; perspektif görünüşü. 


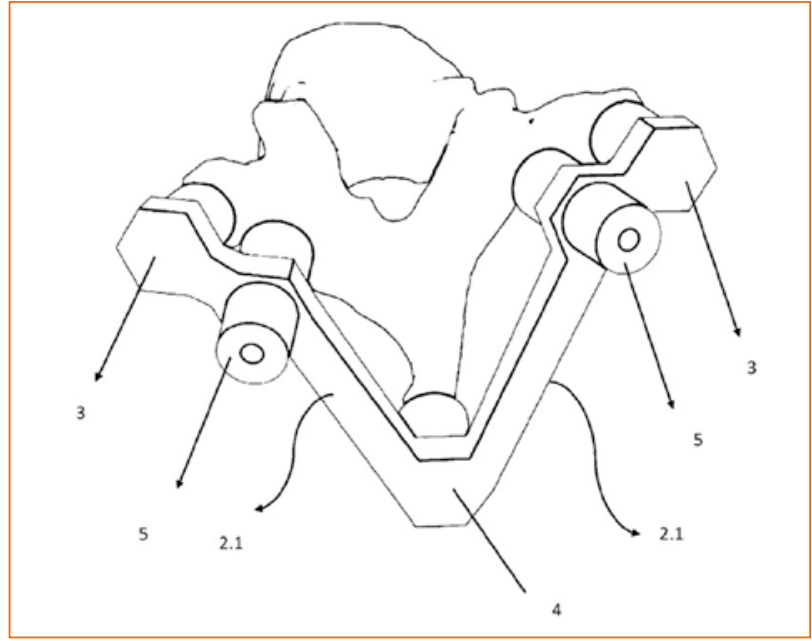

Şekil 11. Kılavuz aparatının vertebra üzerinde örnek bir kullanılışı.

\section{İstemler ${ }^{[1]}$}

"1. Buluş ile kompleks omurga sorunu (deformite, tümör, travma, enfeksiyon, dejeneratif nedenlere bağlı gelişebilen) nedeniyle omurga ameliyatı planlanan hastaların boyun (cervical), gögüs (thoracic), bel (lumbar) vertebraları (1) ve kuyruk sokumu (sacral) kemiği implant (vida) uygulamasının bilgisayarlı planlama ve $3 D$ basılmış kılavuzlar ile hatasız yapılması için kullanılan bir kılavuz aparatı (2) olup özelliği, posterior ligamentöz kompleks tamamen siyırılmadan kemik üzerine oturtulabilen; implant (vida) uygulamasında vidanın gönderileceği eklem çıkıntısına (1.3) oturması için vertebraların (1) benzer olan yapılarından iki yan çıkıntısı (1.1) bir dikensi (1.2) çıkıntısı olmak üzere toplam üç referans noktası baz alınarak oluşturulan, dikensi çıkıntısıyla (1.2) uyumlu yapıya sahip olan bir dikensi çıkıntı yatağına (4); her iki yan çıkıntıları (1.1) ile uyumlu yapıya sahip yan çıkıntı yataklarına (3); vidanın geçirileceği eklem yüzeyi ile uyumlu, operasyonun uygulanacağı kemik yapısına göre, yan çıkıntı yataklarının (3) her birine bağlantı yoluyla (2.1) bağlı veya bitişik olan eklem çıkıntı yataklarına (5); bir eklem çıkıntı yatağı (5) ile bir yan çıkıntı yatağı (3) arasında olacak şekilde bağlantı yollarına (2.1) sahip olması ile karakterize edilmesidir.

2. İstem 1'de bahsi geçen kılavuz aparatı (2) olup özelliği, plastik ve/veya metal malzemeden mamul edilmesidir.

3. Istem 1'de bahsi geçen kılavuz aparatı (2) olup özelliği, vidanın en düzgün şekilde kemik içerisine yerleştirilebilmesi için vida yoluna (5.1) kılavuzluk edecek ve operasyon sirasinda vida yolunun (5.1) sabit bir şekilde vertebra (1) üzerinde kalması için yan çıkıntı yatağının (3), vertebranın (1) yan çıkıntısı (1.1) ile anahtar kilit ilişkisine sahip yan çıkıntı alt yüzeyine (3.2) sahip olmasıdır.
4. İstem 1'de bahsi geçen kılavuz aparatı (2) olup özelliği, vidanın en düzgün şekilde kemik içerisine yerleştirilebilmesi için vida yoluna (5.1) kılavuzluk edecek ve operasyon sırasında vida yolunun (5.1) sabit bir şekilde vertebra (1) üzerinde kalması için dikensi çıkıntı yatağının (4), vertebranın (1) dikensi çıkıntısı (1.2) ile anahtar kilit ilişkisine sahip dikensi çıkıntı yatağı alt yüzeyine (4.1) sahip olmasıdır.

5. İstem 1'de bahsi geçen kılavuz aparatı (2) olup özelliği, sahip olduğu yan çıkıntı yatağı (3) ve dikensi çıkıntı yatağının (4) merkezinde konumlanan ve kılavuz aparatının (2) operasyon sırasında eklem çıkıntı yatağından (5) içerisinden geçirilip vertebraya (1) sabitlenecek olan vidanın operasyon sırasında kaymasını ve istenmeyen hatalara yol açmasını önleyen metal çıkıntı (3.1) yer almaktadır.

6. İstem 1'de bahsi geçen kılavuz aparatı (2) olup özelliği, sahip olduğu eklem çıkıntı yatakları (5), cerrahi operasyon yapılacak hastanın boyun, gögüus ve bel vertebrasına (1) veya kuyruk sokumu kemiğine göre yan çıkıntı yataklarına (3) bitişik veya yan çıkıntı yataklarına (3) bağlantı yolu (2.1) ile bağlı veya yan çıkıntı yatakları (3) ile üst üste binmiş yapıya sahiptir.

7. İstem 1'de bahsi geçen kılavuz aparatı (2) olup özelliği, mukavemetin artırılması ve eklem çıkıntı yatakları (5) ile yan çıkıntı yatakları (3) ve dikensi çıkıntı yatağı (4) arasındaki koordinasyonu sağlamak için bağlantı yollarının (2.1) sayısının birden çok olmasıdır.

8. Istem 1'de bahsi geçen kılavuz aparatı (2) olup özelliği, operasyonun uygulanacağı vertebra (1) veya kemiğin yapısına göre farklı geometrik yapıya sahip olması ile karakterize edilmesidir.

9. İstem 1'de bahsi geçen kılavuz aparatı (2) olup özelliği, sahip olduğu bağlantı yolunun (2.1), yan çıkıntı yatakları (3) ve eklem çıkıntı yatağı (5) ile yekpare olup, dikensi çıkıntı yatağına (4) montajın săglandı̆̆ı ve operasyonu yapacak olan cerrahın matkapla vida yolunu (5.1) açtıktan sonra kılavuz sistemini (2) kaldırıp kemiğe yerleştirilen K-teli üzerinden vidayı serbest elle kemiğe yerleştirmesini sağlayan bağlantı noktasındaki modüler kilite (2.2) sahip olmasıdır.

10. İstem 1'de bahsi geçen kılavuz aparatı (2) olup özelli$\breve{g} i$, sahip olduğu dikensi çıkıntı yatağı (4) ve yan çıkıntı yatakları (3), bağlantı yolunun (2.1) referans alınması ile bağlantı yolunun (2.1) altında veya bağlantı yolunun (2.1) üzerinde kalacak şekilde, tek yönlü uzayan silindirik yapıya sahip olmasıdır.

11. İstem 1'de bahsi geçen kılavuz aparatı (2) olup özelliği, sahip olduğu eklem çıkıntı yatağının (5), bağlantı yolunun (2.1) referans alınması ile bağlantı yolunun (2.1) hem altında hem de üstünde çift yönlü olarak uzayan silindirik yapıya sahip olmasıdır. 
12. Istem 1'de bahsi geçen kılavuz aparatı (2) olup özelliği sahip olduğu vida yolundan (5.1) geçen matkap ucunun, dönme etkisi ile vida yoluna (5.1) zarar vermemesi ve planlama açılarının sapmaması için vida yolunun (5.1) iç yüzeyinden geçirilen paslanmaz çelik boru formuna sahip olmasıdır.

13. İstem 1'de bahsi geçen kılavuz aparatı (2) olup özelliği, sahip olduğu bağlantı yollarının (2.1) içerisinden mukavemetinin sağlamlaştırılması için geçirilen paslanmaz tellere (2.1.1) sahip olmasıdır.

14. Istem 13'de bahsi geçen paslanmaz teller (2.1.1) olup özelliği, metal yapıda ve bağlantı yolunun (2.1) kalınlığı ile orantılı olacak şekilde 0,5-1,5 mm çapına sahip olmasıdır."

\section{YAZARIN KONUYLA ILGILI ÇALIŞMALARI}

Günümüzde kompleks omurga sorunlarının çözümünde ilk basamak rekonstrüksiyon yapılacak omurga segmentinin enstrümante edilmesidir. Biyomekanik olarak en güçlü enstrümantasyon tekniklerinden biri pedikül vidalarıdır. Kompleks omurga sorunlarında omurga normal anatomide olmadı̆̆ için pedikül vidasının el ile serbest yerleştirilmesi zorlaşmaktadır. Bunu çözebilmek için floroskopi ve navigasyon sistemleri kullanılmaktadır. Ancak bu yöntemler ile sadece hasta değil ameliyathane personeli de yüksek doz radyasyona maruz kalmakta, ayrıca bu cihazların pahalı olması nedeniyle sağıı kuruluşuna ciddi finansal yük getirmektedir.

Bundan yola çıkarak hastaya ameliyat öncesi çekilen BT ile omurga modellenmekte ve 3D yazıcılar ile omurgaya uygun pedikül vidası kılavuzları üretilmektedir. ${ }^{[2]}$ Yazar, bu tekniği 2015 yılından beridir skolyoz, kifoz gibi kompleks omurga sorunlarının tedavisinde kullanmakta ve deneyimlerini farklı bilimsel mecralarda sunmaktadır. ${ }^{[3]}$

\section{Teşekkür}

Bu patentin çıkmasında önemli katkıları olan Sayın Kuntay Aktaş ve Sayın Murat Eğri başta olmak üzere Btech Firması çalışanlarına teşekkür ederim.

\section{KAYNAKLAR}

1. Omurilik Kılavuz Aparatı. T.C. Türk Patent Enstitüsü. İncelemesiz Patent Belgesi. No: TR 201508928 B. https:// portal.turkpatent.gov.tr/anonim/arastirma/patent/detayli

2. Senkoylu A, Daldal I, Cetinkaya M. 3D printing and spine surgery. J Orthop Surg (Hong Kong) 2020;28:2309499020927081. Crossref

3. Senkoylu A, Cetinkaya M, Daldal I, Necefov E, Eren A, Samartzis D. Personalized Three-Dimensional Printing Pedicle Screw Guide Innovation for the Surgical Management of Patients with Adolescent Idiopathic Scoliosis. World Neurosurg 2020;S1878-8750(20)31991-4. Crossref 